\title{
AUTUMN OVERDRILLED TAMA RYEGRASS AND CEREALS TO SUPPLEMENT LUCERNE IN THE CENTRAL NORTH ISLAND
}

\author{
J. A. BaArs and J. A. Douglas \\ Soil and Field Research Organisation, MAF, \\ Ruakura Agricultural Research Centre, Hamilton \\ A bstract \\ Two experiments were conducted in which cereals and 'Grasslands \\ Tama' ryegrass were overdrilled into lucerne in autumn, in one \\ experiment following a prior light cultivation. The highest produc- \\ tion was obtained from barley and oats when left uncut from sow- \\ ing until carly spring. Barley was distinctly superior to oats, ryecorn \\ and Tama ryegrass when two cuts were taken in late winter and \\ early spring. Tama ryegrass and to a lesser extent oats depressed \\ lucerne growth, when they were growing and after their disap- \\ pearance. Nitrogen doubled the weed content, where there was \\ inadequate competition from overdrilled species.
}

\section{INTRODUCTION}

OVERDRILLING LUCERNE with annual species to increase winter/ early spring and annual herbage yield has shown some promise in the South Island (Vartha, 1967, 1971).

In the Waikato where barley was overdrilled into lucerne, Elliott (1967) recorded an average increase over three years of $950 \mathrm{~kg}$ dry matter (DM)/ha from two cuts in late May and August, In two further years no increase in production was recorded. Croy and Weeda (1974) reported a much larger increase of $2400 \mathrm{~kg} \mathrm{DM} / \mathrm{ha}$ from overdrilling oats when grazed twice over winter.

For the pumice country, Taylor (1953) described the practice of overdrilling Lolium (multiflorum $\times$ perenne) 'Grasslands Manawa' ryegrass in autumn for augmenting silage yields in spring. However, in this region lucerne is increasingly being used for grazing and both pasture and lucerne have low early spring production (Baars et al., 1975) . Consequently, any way of improving this production would be of distinct advantage to stock management.

There is a general lack of reported experimental work in the North Island on overdrilling winter-active species into lucerne. This paper describes two experiments, one in the pumice country 
and one in the Waikato, in which L. multiflorum Lam. 'Grasslands Tama' Westerwolds ryegrass and three cereals were overdrilled into lucerne in late autumn to assess the effects of these treatments on winter and spring production.

\section{EXPERIM EN TA L}

EXPERIMENT 1

This experiment was sod-seeded on April 29, 1974, into a recently grazed 2-year-old lucerne stand on Horotiu sandy loam at Ruakura Agricultural Research Centre. Plots were 0.13 ha in randomized blocks with three replicates. The treatments were Amuri oats (100 kg/ha), Tama ryegrass $(30 \mathrm{~kg} / \mathrm{ha})$, Amuri oats and Tama ryegrass $(80 \mathrm{~kg} / \mathrm{ha}$ and $30 \mathrm{~kg} / \mathrm{ha})$, each sown with $250 \mathrm{~kg} / \mathrm{ha}$ of superphosphate, and lucerne alone. In mid-August half of each plot received $50 \mathrm{~kg} \mathrm{~N} / \mathrm{ha}$ as urea. Before each grazing by dairy cows an area of $8 \mathrm{~m}^{2}$ was cut with a "Gravely" mower, to assess total dry matter and species composition.

\section{EXPERIMENT 2}

This experiment was sod-seeded after pitch pole harrowing on March 28, 1973, into a closely grazed 13-year-old lucerne stand on Atiamuri sand at Wairakei Research Station. Plots were drill strips $(10 \mathrm{X} 1 \mathrm{~m})$ in randomized blocks with three replicates. The treatments were Tama ryegrass $(30 \mathrm{~kg} / \mathrm{ha})$, CRD ryecorn (100 kg/ha), Carlsberg barley (100 kg/ha) and Onward oats (100 kg/ha) sown with $250 \mathrm{~kg} / \mathrm{ha}$ of a 50:50 superphosphate/ nitrolime mixture, and lucerne alone. The accumulated production from sowing as well as regrowths from cuts in early and midwinter were measured as in Experiment 1 with a "Gravely" mower. This experiment was sod-seeded after 6 weeks of drought and after seeding the rainfall from April until July was $129 \mathrm{~mm}$ below the average of $387 \mathrm{~mm}$.

\section{RESULTS AND DISCUSSION}

\section{EXPERIMENT 1}

The standing production at July 30 and the total and component species yields at each cut from the initial grazing on September 11 are shown in Table 1. The accumulated production by the end of July indicates the slow winter growth of the overdrilled species. In addition there was no overall gain in total yield because of depressions in lucerne growth. By the first cut and 
OVERDRILLING OF LUCERNE

TABLE 1: PRODUCTION OF LUCERNE AND OVERDRILLED ANNUALS IN EXPERIMENT 1. ( $\mathrm{kg} \mathrm{DM} / \mathrm{ha})$

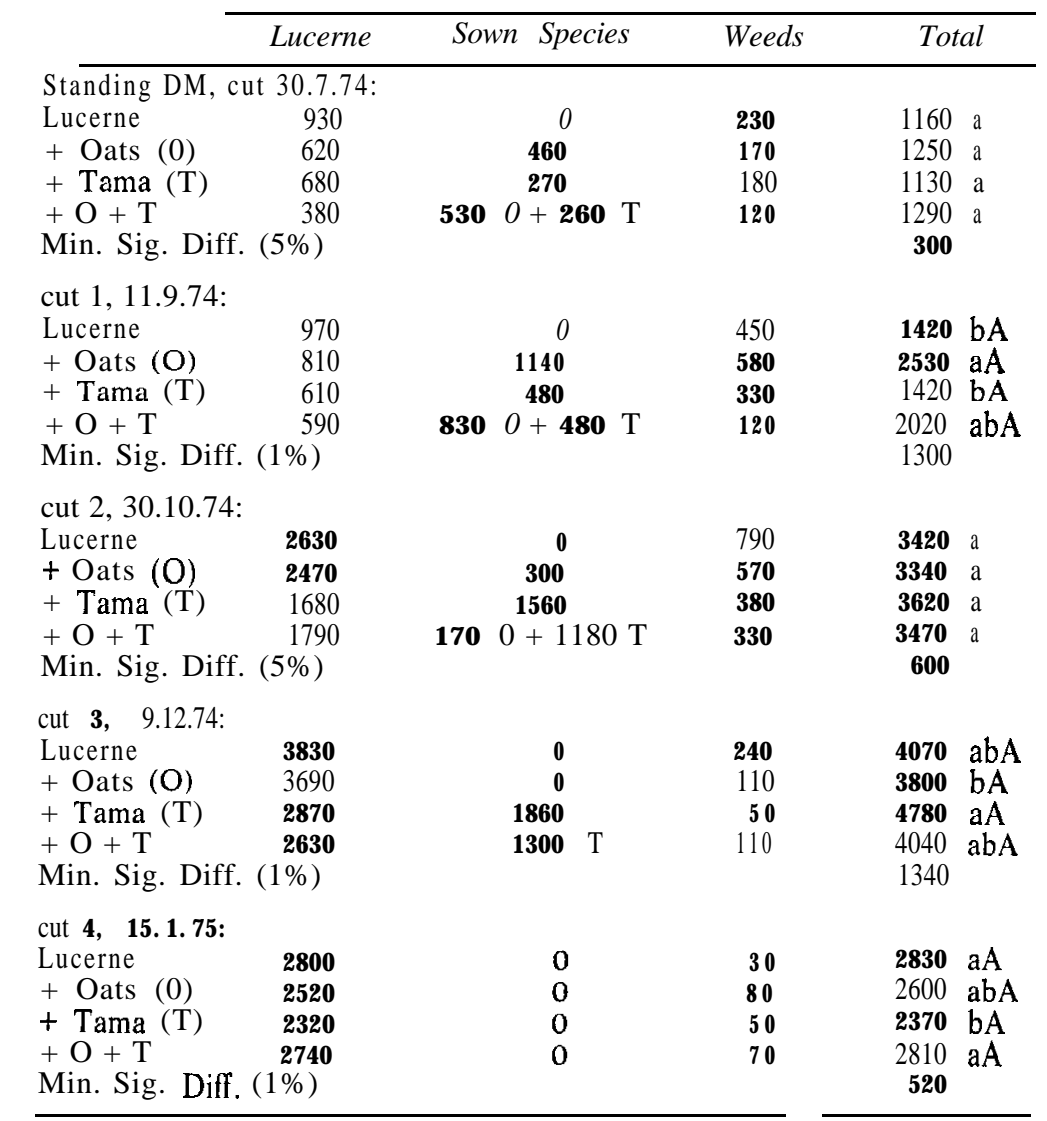

In tables 1, 2 and 3, Duncan's Multiple Range Test: means without a common letter differ significantly (lower case, $P<0.05$; capitals, $P<0.01$ ).

grazing on September 11 the oats in particular had shown rapid late winter growth and they almost doubled total production. Tama produced about half the yield of oats, but there was no addition in total yield because both the lucerne and weeds fractions were depressed. Oats and Tama were intermediate in production but the lucerne was again suppressed.

In subsequent cuts there was little or no regrowth from the oats but Tama production continued into summer. Its bulk came 
PROCEEDINGS N.Z. GRASSLAND ASSOCIATION

TABLE 2: EFFECT OF LATE WINTER N APPLICATION ON EARLY SPRING CUT (11.9.74), Experiment 1.

$(\mathrm{kg} \mathrm{DM} / \mathrm{ha})$

\begin{tabular}{|c|c|c|c|c|c|}
\hline & Lucerne & Sown & Species & Weeds & Total \\
\hline \multicolumn{6}{|c|}{ Lucerne: } \\
\hline \multirow{2}{*}{$\begin{array}{lll}\text { No } & N \\
& N\end{array}$} & 970 & & 0 & 450 & $1420 \mathrm{a}$ \\
\hline & 830 & & 0 & 980 & $1810 \mathrm{a}$ \\
\hline \multicolumn{6}{|c|}{ Lucerne + Oats: } \\
\hline \multirow{2}{*}{$\begin{array}{rr}\mathrm{No} & \mathrm{N} \\
\mathrm{N}\end{array}$} & 810 & & 1140 & 330 & $2530 \mathrm{a}$ \\
\hline & 690 & & 1330 & 640 & $2660 \mathrm{a}$ \\
\hline \multicolumn{6}{|c|}{ Lucerne + Tama: } \\
\hline \multirow{2}{*}{$\begin{array}{rr}N o & N \\
& N\end{array}$} & 610 & & 480 & 240 & $1420 \mathrm{bA}$ \\
\hline & 820 & & 840 & 440 & $2110 \mathrm{aA}$ \\
\hline \multicolumn{6}{|c|}{ Lucerne + Oats + Tama: } \\
\hline \multirow{2}{*}{$\begin{array}{ll}\mathrm{N} 0 \mathrm{~N} \\
\mathrm{~N}\end{array}$} & 590 & $990 \mathrm{O}$ & $+380 \mathrm{~T}$ & 60 & $2020 \mathrm{a}$ \\
\hline & 430 & 7300 & $+660 \mathrm{~T}$ & 450 & $2270 \mathrm{a}$ \\
\hline \multicolumn{5}{|c|}{ Min. Sig. Diff. $5 \%$ with pairs } & 590 \\
\hline
\end{tabular}

in December, similar to the pattern of production from L. multiflorum Lam. 'Grasslands Paroa' ryegrass in the Waikato (Elliott, 1967). The cut in January showed the lucerne was still depressed by Tama, even after the latter had disappeared. Similar depressions from annual ryegrasses have been reported by Hoglund (1972) and Elliott (1967).

The effect of the nitrogen application applied in mid-August is shown in Table 2. Tama and the weed components were markedly increased by the nitrogen, but there was little effect on the oats. The response of $13 \mathrm{~kg} \mathrm{DM} / \mathrm{kg} \mathrm{N}$ for the Tama treatment was within the range of values recorded by Vartha (1971) in Canterbury. There were no residual $\mathrm{N}$ effects after the first grazing.

\section{EXPERIMENT 2}

The accumulated production from sowing, at three measurement times, is shown in Fig. 1. Appreciable yield increases did not take place until late winter/early spring at which time the cereals, apart from ryecorn, significantly outyielded Tama. Barley gave better production than oats during the winter but by the final cut in early October there was little difference. The lucerne growth over the winter period was minimal and when it began to grow in the spring it was suppressed by the overdrilled species, particularly barley and oats. 


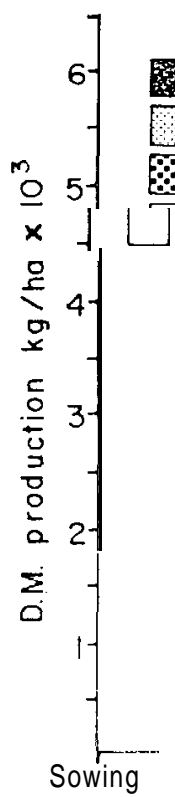

\section{Weeds}

Dead matter

Overdrilled species

\section{Lucerne}

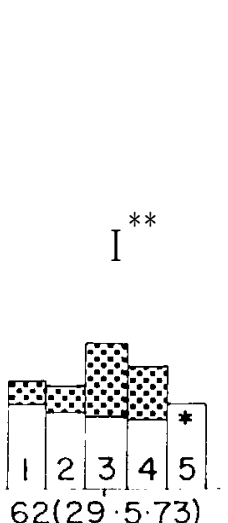

Days after sowing

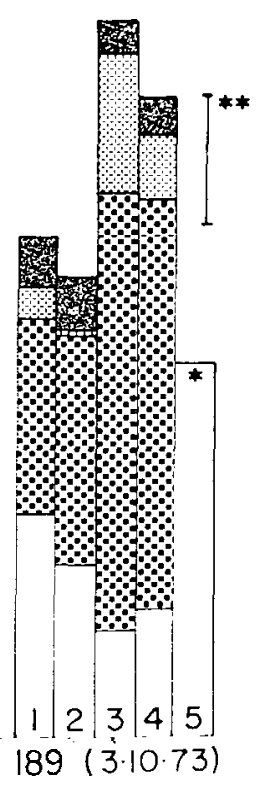

FIG. 1: Accumulated production at three dates $(29.5 .73,7.8 .73$ and 3.10.73) after sowing in Experiment 2.

Treatments:

1. Tama + Lucerne. 2. Ryecorn + Lucerne. 3. Barley + Lucerne. 4. Oats

+ Lucerne. 5 Lucerne control. * No Dissection. ** Min. Sig. Diff.

$$
(P=0.01)
$$

Production from the two- and three-cut systems compared with the single cuts is shown in Table 3. In no case did the cut and recut systems outproduce that derived from the single cut at the end of the period. The three-cut system over the winter/ early spring gave no production increase over that produced by lucerne alone, even though the sown species gave significant component yields.

Any reliance on regrowth of the sown species was of little benefit. This is indicated especially by oats under the three-cut system only producing $17 \%$ of the yield when left to grow until the final cut (one-cut system). Similar figures for barley were $34 \%$, ryecorn $65 \%$, and Tama $60 \%$. Some of the previous failures with overdrilled cereals (e.g., McLeod and Douglas, 1976; Vartha, 1967) also indicate the inability of cereals, particularly oats, to regrow from early grazing. However, ryecorn did show an ability 
TABLE 3: TOTAL PRODUCTION OF LUCERNE-ANNUAL SPECIES AND LUCERNE UNDER THREE CUTS (29.5.73, 7.8.73 AND 3.10.73), TWO CUTS (7.8.73, 3.10.73) AND ONE CUT (3.10.73) SYSTEMS.

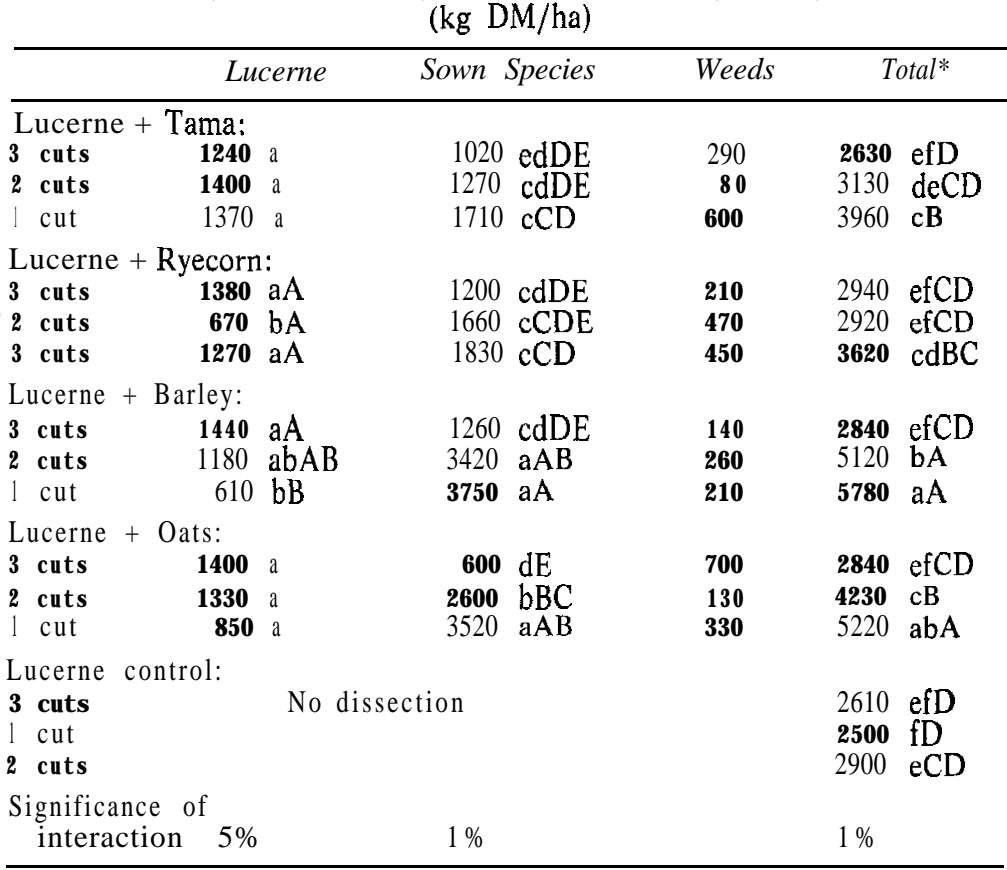

*Including dead matter.

to withstand early defoliation and if its production was similar to the other cereals this attribute would be a considerable advantage. There are some data to suggest that ryecorn is particularly sensitive to low nitrogen conditions (McLeod and Douglas, 1976; K. Cottier, unpublished data).

Where the early cut was not taken (two-cut system) the barley and oats in particular gave high production without causing the severe depression to the lucerne under the one-cut system.

\section{G E N E R A L}

In both trials Tama ryegrass showed negligible growth from the end of May to August in comparison with oats and barley. Vartha '(1967, 1971) and Janson (1975) stressed the importance of sufficient moisture in autumn for early Tama establishment to have high winter and early spring production, Under cultivated condi- 
tions Tama production in winter is improved by early autumn sowing (Crouchley and Bircham, 1971). However, early sowing, especially in the pumice country, is frequently impossible because of dry autumn conditions.

Experiment 2 recorded considerably higher yields than Experiment 1 in spite of dry cold conditions after sowing. Earlier sowing, nitrogen fertilizer at drilling, and prior cultivation may all have contributed to this difference. Robinson and Cross (1957) recorded better establishment and growth of overdrilled grass species after light cultivation on clover-dominant swards on pumice country soils near Whakamaru.

Any gain from ovcrdrilling Tama and cereals has to be weighed against the reduction in lucerne as found in both experiments. Further, one has to consider a possible lowering of subsequent lucerne spring production, following winter grazing as reported by Janson (1975) in Canterbury and/or reductions in late spring yields caused by early spring defoliation (Vartha, 1967).

\section{CONCLUSION}

Overdrilling lucerne in autumn with cereals could be of considerable value for late winter/early spring breakgrazing or to conserve large quantities of forage as silage or hay. Barley would be a better choice than oats for breakfeeding because of its better regrowth ability.

Tama has a greater ability than the cereals to withstand several grazings, but in these experiments its lack of growth and its depression of lucerne have led to no great increase in production.

Further work must be carried out on surface cultivation, time of overdrilling, and grazing management to establish the value of this technique in annual lucerne management.

\section{ACKNOWLEDGEMENTS}

The technical assistance of staff of Wairakei Research Station, Nutrition Centre, Ruakura, and Agronomy Section, Soil and Field Research Organisation, MAF, is gratefully acknowledged. We are indebted to $\mathrm{C}$. Dyson for statistical analyses.

\section{REFERENCES}

Baars, J. A.; Radcliffe, J. E.; Brunswick, L., 1975. Seasonal distribution of pasture production in New Zealand. VI. Wairakei, pasture and lucerne production. N.Z. Il exp. A gric., 3: 253-9.

Crouchley, G.; Bircham, J. S., 1971. Winter greenfeed production in the Wairarapa. N.Z. Jl Agric., 122: 36-7. 
Croy, B. G.; Weeda, W. C., 1974. Beef production on pasture and lucerne. Proc. N.Z. Grassld Ass., 36: 73-8.

Elliott, I. L., 1967. Lucerne in the North Island of New Zealand. In The Lucerne Crop (ed. R. H. M. Langer), pp. 298303. Reed, Wellington. Hoglund, J. H., 1972. Effect of defoliation management and 'Tama' overdrilling on weed yields of irrigated lucerne. Proc. N.Z. Weed \& Pest Control Conf., 25: 96-100.

Janson, C. G., 1975. Influence of autumn-winter lucerne management and overdrilled 'Grasslands Tama' on spring herbage yields under irrigated and dry conditions. N.Z. $/ l$ exp. Agric., 3: 229-34.

McLeod, C. C.; Douglas, J. A., 1976. Autumn overdrilling of lucerne with cereals and annual ryegrasses to improve spring production in South Canterbury and North Otago. Proc. N.Z. Grassid Ass., 37: 228-36.

Robinson, G. S.; Cross, M. W., 1957. Overdrilling pumice pastures. N.Z. Il Agric., 91: 283-S.

Taylor, C. R., 1953. Oversowing lucerne with short-rotation ryegrass. Ibid., S7: 425-6.

Vartha, E. W., 1967. Lucerne overdrilled with grasses for grazing. In The Lucerne Crop (ed. R. H. M. Langer), pp. 177-85. Reed, Wellington.

Vartha, E. W., 1971. Overdrilled winter-growing annual grass to supplement lucerne. Proc. N.z. Grassid Ass., 33: 115-23. 